\title{
Koululait toivat kattavan koulutuksen arvioinnin
}

\author{
"Kun ihmisluontoon kuuluu toisten arvostelu, miksi tätä \\ piirrettä ei hyödynnettäisi myös koulutuksen \\ arvioinnissa", ehdottaa opetusneuvos Pentti Yrjölä.
}

Vuoden alusta voimaan tulleissa koululaissa on kaikissa pykälät koulutuksen arvioinnista. Kun muussa koulutuksessa arviointivastuu on koulutuksen järjestäjällä, vapaassa sivistystyössä se on oppilaitoksella. Opetusneuvos Pentti Yrjölä opetushallituksesta pitää tätä vapaan sivistystyön kannalta erittäin merkittävänä asiana: "Oppilaitoksen tulee arvioida siis antamaansa eli oppilaitoksessa tapahtuvaa koulutusta ja sen vaikuttavuutta.“

Mitä sitten vaikuttavuudella tarkoitetaan? Yrjölän mielestä eduskunnan sivistysvaliokunnan mietintö koululakiesityksestä on tutustumisen väärti, koska siellä koulutuksen arviointia ja vaikuttavuutta on käsitelty laajasti.

Sivistysvaliokunnan mukaan vaikuttavuudella tarkoitetaan neljää viittä eri asiaa:

1 Ensiksikin oppimistulosten saavuttamista, mikä on aivan keskeistä esimerkiksi peruskoulussa ja lukiossa, jossa on valtakunnalliset opetussuunnitelmaperusteet.

"Aikuiskoulutuksessa ja vapaassa sivistystyössä erityisesti ei ole olemassa vastaavia valtakunnallisia tavoitteistoja. Mutta kyllä jokaisella itseään kunnioittavalla opistolla täytyy olla selkeitä tavoitteita siitä, mihin koulutuksella pyritään. Mitä muuta varten koulutusta järjestettäisiin?“, Yrjölä kysyy.

1 Toinen asia on vaikeampi: oppimaanoppimisvalmiudet eli miten opiskelija kehittyy op- pijana koulutuksen kestäessä.

1 Mukaan lasketaan myös kommunikaatiovalmiudet ("Suomalaisiahan arvosteltu sen puutteista“) sekä

1 itsensäkehittämishalukkuus ja -valmius.

Miten yksittäisillä koulutustapahtumilla voi olla noin kauaskantoisia tavoitteita kuin kommunikaatiovalmiudet. Ne ovat hyvin pitkäkestoisia tavoitteita?

"Ei tietenkään yksittäiseltä kurssilta voida sellaista edellyttää. Mutta nämäkin tavoitteet voidaan muistaa opetuksesta suunnitteltaessa. Esimerkiksi kansalaisopiston kurssin vetäjä voi pitää ne mielessä.“

1 Viides vaikuttavuusulottuvuus on se, mihin ihmiset menevät koulutuksen jälkeen. Peruskoulun, lukion ja ammatillisen koulutuksen kannalta sijoittuminen jatkokoulutukseen tai työelämään on aivan keskeinen kysymys.

"Muodollisen koulutuksen suhteen vaikuttavuuden määrittely on selvä. Aikuiskoulutuksessa kysymys on sen sijaan enemminkin siitä, onko ihminen kokenut hyötyneensä saamastaan koulutuksesta“, Yrjölä linjaa.

Onko siis oppilaitksten velvollisuus tästä lähtien seurata sitä, minne heidän koulustaan lähteneet menevät tai pääsevät? 


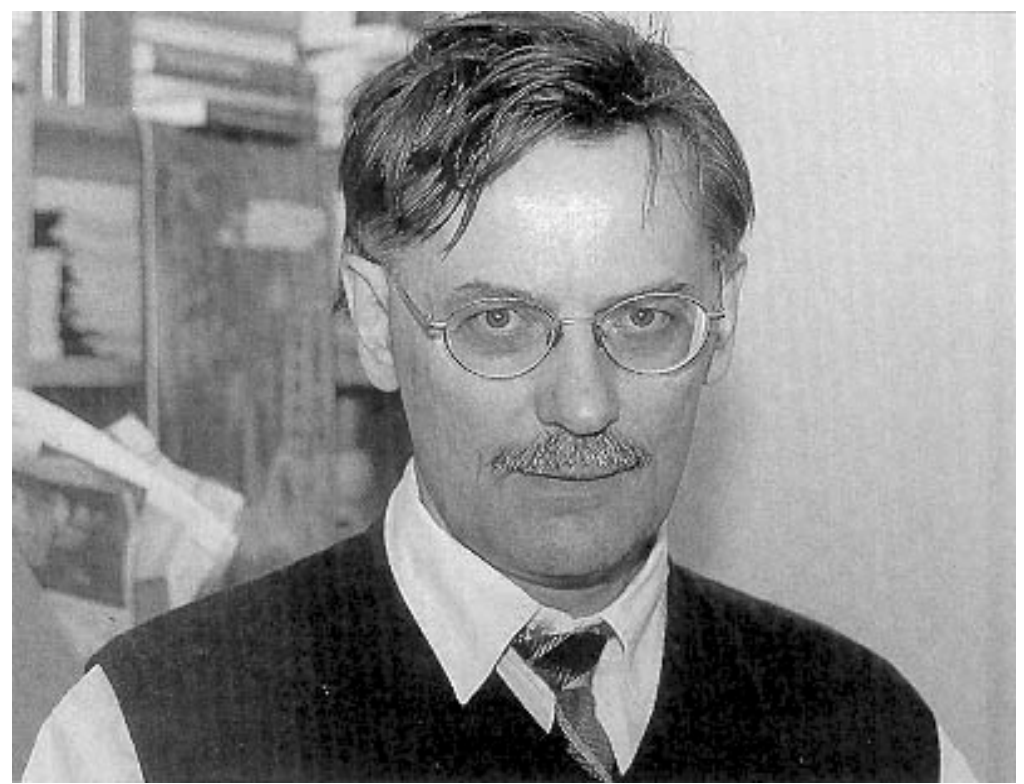

Hallitus kirjasi ohjelmaansa ammattikorkeakoulujen kattavan kansainvälisen arvioinnin. Ulkomaisia arvioijia on ollut mukana aiemminkin, mutta nyt lienee odotettavissa jotain aiempaa vakuuttavampaa koulutuksen tällä lohkolla", opetusneuvos Pentti Yrjölä uskoo.

"Kyllä"

Onko sellaiseen rahkeita? Ei kai kukaan koulutuksen järjestäjä voi ottaa ihmisten kohtaloita käsiinsä?

"Ei niin. Vapaassa sivistystyössä ja ammatillisessa aikuiskoulutuksessa kysymys onkin siitä, kokevatko ihmiset hyötyneensä koulutuksesta. Sen sijaan muodollisen koulutuksen järjestäjien pitää luoda jonkinlainen seurantasysteemi.Laki on jo astunut tältä osin voimaan.“"

Sivistysvaliokunnan mietinnön lisäksi Pentti Yrjölä pitää tärkeänä myös kahta muuta asiakirjaa. Toinen on vuodelta 1998 valtion hallintopoliittinen periaatepäätös ja toinen, tuoreempi asiankirja on Lipposen II-hallituksen hallitusohjelma, jossa on niukka maininta myös muodollisen koulutuksesta arvioinnista. "Ilmeisesti valtion hallinnossa tulosohjaus ja tulostavoitteiden määrittely tulevat entistä keskeisimmiksi. Siitä seuraa, että opetushallinnossa panostetaan aiempaa enemmän tuloksellisuuden arviointiin eli siihen, mitä hyötyä koulutuksesta on ollut ihmisille ja yhteiskunnalle.

Ohjelmassa todetaan erikseen, että ammattikorkeakouluista tehdään korkeatasoinen, kansainvälinen arviointi“, Yrjölä toteaa.

Arviointejahan on tehty tähänkin asti?
"Kyllä, korkeakoulujen arviointineuvoston toimesta. Tähän asti tehdyissä arvioissa on ollut mukana ulkomaisia arvioijia, mutta tällä kertaa on ilmeisesti kyse jostain suuremmasta, kun se on kirjattu hallitusohjelmaan.“

"Korkeakoulujen arviointineuvostohan toimii hieman eri logiikalla kuin opetushallituksen arviointiyksikkö. Me tartumme asiaan huomattavasti suoremmin ja arvioimme tietyllä arviointimallilla kaikkia koulutuksia. Arviointineuvosto luottaa nimenomaan korkeakoulujen ja ammattikorkeakoulujen itsearviointiin. Niillä on keskeisinä lähtökohtina benchmarking-ajattelu ja kansainvälinen vertailtavuus.

"Kolmas asiakirja on valtion opetusministeriön päätös koulutuksen ulkopuolisen arvioinnin toimeenpanosta ja arvioinnin perusteista. Päätöksessä on puitteet valtakunnalliseen arviointiin, mikä on opetushallituksen arviointiyksikön tehtävä. Systeemihän toimii siten, että koulutuksen kehittämissuunnitelmassa määritellään tiettyjä painopisteitä. Parhaillaan valmistellaan uutta kehittämissuunnitelmaa ensi vuosituhannelle. Vuosittaiset arviointihankkeet ratkaistaan opetusministeriön ja opetushallituksen välisessä tulossopimuksessa.“

Opetusneuvos Yrjölällä on paraikaa menossa ammattitutkintojärjestelmän arviointi. Käsi- ja taideteollisen ammatillisen koulutuksen arvioinnin 
sisällä on myös aikuiskoulutuksen arviointi. Nyt on olemassa selvä viritys sekä kansanopistojen että oppisopimuskoulutuksen arvioinnille.

\section{Miten opetushallitus edistää arviointia?}

"Merkittävin asiakirja on Koulutuksen tuloksellisuuden arviointimalli. Se on aikuiskoulutuksen kannalta on keskeinen lähtökohta, kun oppilaitosmuotoja lähdetään arvioimaan. On myös lainsäädäntö, sivistysvaliokunnan mietintö, koulutuksen tuloksellisuuden arviointimalli, opetusministeriön päätös ja koulutuksen kehittämissuunnitelma."

"Viranomaisella ei ole kuitenkaan oikeuksia eikä välineitä puuttua yksittäisen oppilaitoksen arviointijärjestelmään. Voimme vain antaa tiettyjä suosituksia. Selvää on luonnollisesti, että valtakunnallinen arviointi toteutetaan tiettyjen lähestymistapojen mukaan. Opetushallituksessa valmistetaan itsearvioinnin tueksi aineistoja, jotka sopivat suoraan käytössä olevaan arviointimalliin. Tämän vuoden aikana oppilaitokset saavat materiaalia siitä, millaista itsearviointikulttuuria valtakunnallinen arviointi suosii“, Yrjölä lupaa.

\section{Omatoimisudelle pyyhkeitä}

Pentti Yrjölä ei ole järin innostunut oppilaitosten omaperäisistä ratkaisuista:

"Tuntuu siltä, että monissa oppilaitoksissa on halua ja intoa ryhtyä luomaan aivan uusia kulttuureja. Kulutetaan voimavaroja erilaisiin itsearvioinnin ja laadun kehittämisjärjestelmien etsimisiin. Toivottavasti pysähdyttäisiin hetkeksi ja mietittäisiin sitä, mikä on todella tärkeää. Koska oppilaitoksissa kuitenkin on toimintasuunnitelma, talousarvio, toimintakertomus ja tilinpäätös, itsearviointiosioiden lisääminen näihin on huomattavasti helpompaa, kuin lähteä luomaan aivan erillistä toimintakulttuuria. Vaarana on kuitenkin se, että itsearvioinnista tulee vain rehtorin johdattelevaan puheenvuoroon yksi kappale. Pitää lähteä arvioimaan sitä, mitä oppilaitoksessa todellakin on saatu aikaan. Jos oppilaitokset kytkevät itsearviointinsa toimintakerto- mukseen, se tulee automaattisesti dokumentoitua. Ja sitä pidän tärkeänä.“

Yrjölän mielestä oleellista on systeemi, joka selvittää toiminnan kannalta keskeisiä asioita. Sen tulee olla mahdollisimman selkeä ja edullinen. Sen pitää myös paljastaa mahdolliset epäonnistumiset ja epäkohdat, kuin myös kertoa hyvistä tuloksista. Itsearvioinnista ei saa tulla luuta, jolla lakaistaan roskat maton alle.

"Olisi myös hyvä, että olisi joku kriittinen, luotettava ystävä, esimerkiksi naapurioppilaitoksesta, joka ottaisi tehtäväkseen ruotia itsearviointijärjestelmää.“

\section{Mikä valmius kentällä on?}

Opetushallitus kahtena vuonna panostanut todella merkittävästi kansalaisopistojen itsearvioinnin kehittämiseen. Siellä on olemassa erilaisia arviointimalleja, joita voi soveltaa omaan oppilaitokseen.

Kansanopistoissa on käytössä laaja Otavan Opiston itsearvioinnin kehittämishanke. Opintokeskuksissa on ollut pienempiä hankkeita ja ammatillisissa aikuiskoulutuskeskuksissakin omat itsearvioinnin ja laadun kehittämishankkeensa.

Kun opetushallitus vuonna 1992 perustettiin, oli aikuiskoulutuksen linjalla viisi itsearviointiprojektia. Ne elivät aikansa ja kuihtuivat osittain pois, eikä niistä tullut vielä varsinaisia käytäntöjä.

"Nyt on sen sijaan olemassa tausta-aineistoa, jota voi hyödyntää. Kannattaa miettiä, ottaako yhteyttä konsulttiin vai kehittääkö itsearviointimallin tai -tavan itse. Jos oppilaitoksen rehtori ja opettajat ovat rehellisiä, he tietävät oman toimintansa kaikkein parhaiten ja sille pohjalle on hyvä rakentaa, eikä suinkaan ulkopuolisten viisauksien ja tietojen varaan. Tässä asiassa tulee luottaa terveeseen talonpoikaisjärkeen. Toisten arviointi kuuluu ihmisluonteeseen, joten miksi tätä luonteenpiirrettä ei käytettäisi hyväksi oman toiminnan arvioimisessa. Aikuiskoulutuksessa on puhuttu reflektiivisyydestä kyllästymiseen saakka ja siitähän tässä on organisaation kannalta kyse“, muistuttaa Yrjölä. 


\section{Oppimisen ilo tärkein vapaassa sivistystyössä}

\section{Ovatko arviointi edistynyt hyvin?}

"Into ja avoimuus ovat ainakin positiivisia asioita. Aikuiskoulutuksen arvioijaa askarruttaa eniten se, että opiskelijat ovat hukassa. Luodut tilastojärjestelmät seuraavat opetustunteja ja kurssilaisten määrää, mutta ihmisestä ei ole oikeastaan kukaan kiinnostunut. Minkälaisia opiskelijat ovat, montako tuntia he opiskelevat ja ennen kaikkea, mitä he saavat opiskelustaan? Mitkä ovat niitä yhteisiä indikaattoreita, joilla aikuiskoulutuksen toimintaa seurataan, ja mitkä ovat kullekin toimintamuodolle omimpia indikaattoreita?"

"Vapaassa sivistystyössä olennainen vaikuttavuusindikaattori on ilo ja hyöty, jonka ihminen saa oppiessaan. Mutta miten niitä mitataan? Kenenkään intressissä ei ole luoda vapaaseen sivistystyöhön kovia oppimistulosten vaikuttavuusmittareita."

\section{Pitäisikö yliopistojen tutkia enemmän vapaan sivistyksen tonttia?}

\section{Pentti Yrjölä:}

"Yliopistot eivät ole viime vuosina juurikaan panostaneet vapaan sivistystyön tutkimiseen. Väitöskirjat ovat vapaan sivistystyön omien veteraanien tekemiä. Kun vuosikymmenen puolivälissä tein kansalaisopistojen valtakunnallista arviointia, kansalaisopistoista löytyi merkittävä määrä pro gradu -töitä ja muutamia väitöskirjoja. Kun muutama vuosi sitten arvioin opintokeskuksia, niistä sai hakea pro gradu -töitä. Toivon, että oppilaitokset käyttävät nyt talonpoikaisjärkeään ja selvittävät, minkälaisia systeemejä muut saman alan oppilaitokset ovat kehittäneet ja soveltavat niitä omiin toimiinsa. Sillä tavoin pääsee varmimmin parempaan tulokseen.“

\section{Tehokkuus ja taloudellisuus}

Arvioinnissa tulee vaikuttavuuden lisäksi kiin- nittää huomiota tehokkuuteen eli siihen, tehdäänkö asiat parhaalla mahdollisella tavalla, ja luonnollisesti myös taloudellisuuteen. Valtiovallan oikeus arvioida vapaata sivistystyötä ja ammatillista aikuiskoulutusta perustuu siihen, että valtio on keskeinen rahoittaja. Se haluaa tietää, mihin rahat menevät ja mitä niillä saadaan aikaiseksi.

Pentti Yrjölän mukaan aikuiskoulutuksen rahoitusjärjestelmien arviointi on ollut jatkuvasti esillä ja se tuntuu olevan niin vaikea asia, että se ei vielä pariin-kolmeen vuoteen tule arviointihankkeeksi. "Mutta se on kyllä niin vakava asia, että tulisi selvittää millä tavalla rahoitusjärjestelmä ohjaa toimintaa. Ammatillisen lisäkoulutuksen pedagogisessa arvioinnissa näkyy rivien välistä, että maksupalvelutoiminta on keskeinen elementti määritettäessä, millä tavoin koulutus toteutetaan."

"Arvioijan suurin ongelma on ns. mutu-tieto. Toiminnasta sekä sen taloudellisuudesta ja vaikuttavuudesta voi olla mielikuvia, mutta arvioijan ammattitaito nojaa siihen arviointiaineistoon, jota hänellä on, ja arviointiaineistojen tulkintaan. Arviointiprosessin tulee olla mahdollisimman avoin niin, että kuka tahansa arvioinnista kiinnostunut henkilö, voi lähteä seuraamaan arvioijan työtä jälkikäteen, katsoa aineistot läpi ja miettiä, mitä tulkintoja arvioija on aineistonsa pohjalta tehnyt.“

"On selvää, että asioita tulkitaan eri tavalla. Tulkinnan jälkeen on kysymys siitä, ovatko arvioinnin johtopäätökset uskottavia. Arvioinnin perimmäinen tarkoitus on ohjata ja kehittää toimintaa siten, että käytettävissä olevat voimavarat käytetään mahdollisimman järkevästi. Se on aina poliittinen päätös. Arvioija esittää aineistonsa perusteella tietyn tulkinnan. Toisaalta rahojen jakaja lukee arviointia omalla tavallansa", Pentti Yrjölä muistuttaa. 